\title{
Solid waste management: Directorate of Kirkuk Municipality landfill model
}

\author{
M. Nawzad Abdula Karem \& M. Towana Abdulmajed Ahmed \\ Directorate of Kirkuk Municipality, Kirkuk, Iraq
}

\begin{abstract}
In this research the reasons for increasing solid waste have been addressed and then waste classifications followed by the basic components of the system for waste treatments have been shown. The study addresses the Kirkuk landfill project and explains the necessary features for the landfill project location, the specifications, and necessary treatments. We have concluded the research by proposing ways to ensure the expansion of the project.
\end{abstract}

\section{Introduction}

The developments in human societies, and the shift from rural to the city communities, led to the increase in the number of city residents and thus increasing human consumption of materials which has caused the significant increase in solid waste. Municipality is considered as the most important institutions taking responsibility to provide services to citizens. The process of waste collection and treatment is the basic tasks the municipality should focus on; the accumulation of solid waste needs urgent solution through right ways. The city of Kirkuk is considered as one of the leading cities in Iraq in the introduction of the landfill system. The city is near to Koya city so that we focus on it in order to take advantage of the city's experience in this field.

\section{Solid waste management in the city of Kirkuk}

The increased number of population, raising the cost of living, industrial and agricultural progress, and the lack of appropriate methods to collect, transport 
and process the solid waste caused an increase in the amount of waste. Therefore the environmental elements are polluted such as water, soil, air and the depletion of natural resources in many areas in the world. In all countries of the world solid waste management has become a necessity to maintain public health and safety.

Solid waste increases as a result of:

- Rapid population growth.

- Economic growth.

- Changes in the style of the consumers.

- Other changes in lifestyle, availability of markets, promotion of goods, political pressures, technological progress, etc.

Economic development is generally accompanied by an increase in solid waste production.

Solid waste project is known as removable materials; the owner wants to get rid of them so that its collection, transportation, and treatment process is in the interest of the community [1].

\section{Waste classification}

- Household waste.

- Commercial waste.

- Industrial waste.

- Agricultural waste.

- Medical and hospital waste.

- Construction and demolition waste [2].

\subsection{The basic components of the system}

The main areas that require study, planning, and implementation effectively and efficiently are:

- Waste production.

- Waste storage.

- Waste collection process.

- Collection system/waste transport.

- Treatment process/waste disposal.

\section{Landfill project in Kirkuk}

Landfill project is a place where household solid waste is put; there are landfill sites for medical and nuclear waste according to designs prepared for this purpose and by engineering and environmental determinants of each of these types of waste. 


\section{The necessary characteristics for a waste landfill site}

- The site should be consistent with the current and future land uses in the region.

- $\quad$ Easy access in all seasons of the year.

- $\quad$ Soil sufficient to cover the waste.

- Causes no contamination of water sources.

- Causes no harm to any significant natural resources.

- It should be acceptable by the neighboring population.

- Wide space to contain the waste produced from the area.

- It should not be costly.

- It should be in the opposite direction of the prevailing wind in the area.

\section{Site selection}

The site is selected according environmental and engineering standards; the project is located in the Zindanh road district between Taza and Laylan, 3km away from the Baghdad/Kirkuk main road.

1. Total landfill project area is 480 acres.

2. Project area is 240 acres.

3. Area of the cell is $(300 * 600) \mathrm{m}^{2}$, an area of 72 acres 1 .

4. Average depth is $4 \mathrm{~m}$.

5. The cell is buried with 2 layers of red soil and the thickness of each layer is $30 \mathrm{~cm}$.

6. The black felt Spanish made layer is furnished with $1.5 \mathrm{~mm}$ thickness to prevent squeezer into the soil.

7. Furnishing two layers of gravel runway with $30 \mathrm{~cm}$ thickness of each layer.

8. Extending 8 and $12 \mathrm{ml}$ pipeline, inside and outside the cell to collect the accumulated liquids from the waste and deliver them to the treatment plant.

9. Liquid treatment plant is established from the waste.

10. A stream is created to drain rain water to prevent its arrival into the waste [3].

\section{What happens to the municipal waste in the landfill?}

- The organic materials that have the ability to easily disintegrate such as food waste, wood, several paper products, as well as some tissue decomposed by a group of organisms found in municipal waste.

- Group of germs convert organic material into organic acids , and another group of germs turn organic acids into methane and carbon dioxide (landfill gas)

- In addition to the release of some volatile organic compounds [2]. 


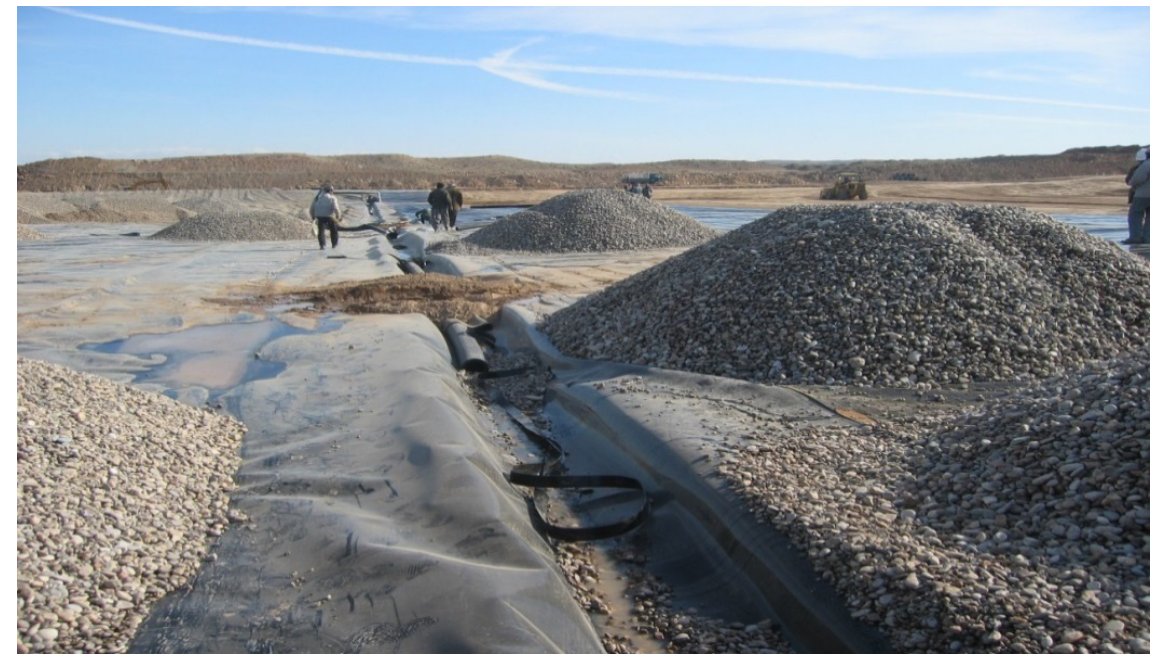

Figure 1: $\quad$ The gravel runway process.

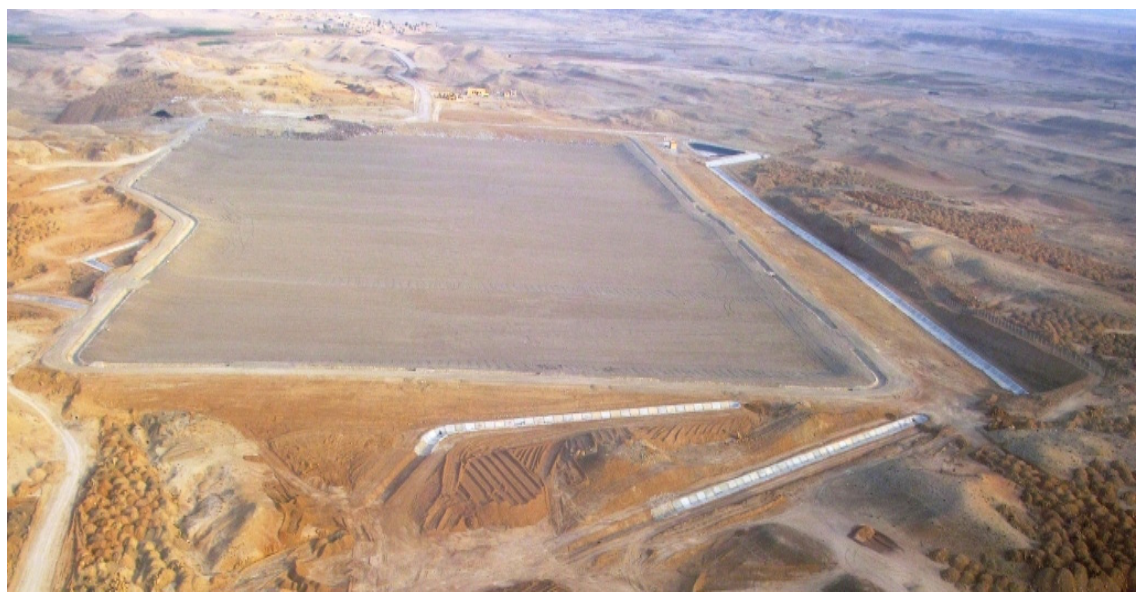

Figure 2: $\quad$ Cell ready to receive waste.

\section{Filtrate treatment building}

Filtrate treatment system equipment located within the building includes:

- $\quad$ One air compressor.

- Pump air filtering compressor, number (2).

- One slag filtering compressor.

- $\quad$ Pumps to take the $\mathrm{pH}$ samples, number (2).

- $\quad$ The $\mathrm{pH}$ measure, number (1).

- $\quad$ Chemical feed pumps $\mathrm{NaOH}$, number (3). 


\section{Air blower platform located behind the building}

- Three pumps with low air pressure for the purpose of mixing pools.

- One pump with low air pressure for the purpose of the filtrate pool solver.

\subsection{Filtrate}

- The filtrate contains large amounts of organic and inorganic materials.

- It contains large amounts of heavy metals due to putting waste with mineral contents.

- The ammonia, chloride, acidic, materials with heavy metal concentrations are the major toxic pollutants.

\subsection{Filtrate treatment: metal removal}

- The removal of soluble metal ions in the texture through ion deposition like metal hydroxide is considered as traditional methods used.

- The process is adjusted by regulating the $\mathrm{pH}(9.5 \mathrm{pH}$ optimum deposition).

- By adding sodium hydroxide to increase the proportion of the $\mathrm{pH}$; the metal hydroxide components produced from that become insoluble and thus precipitate out of the texture.

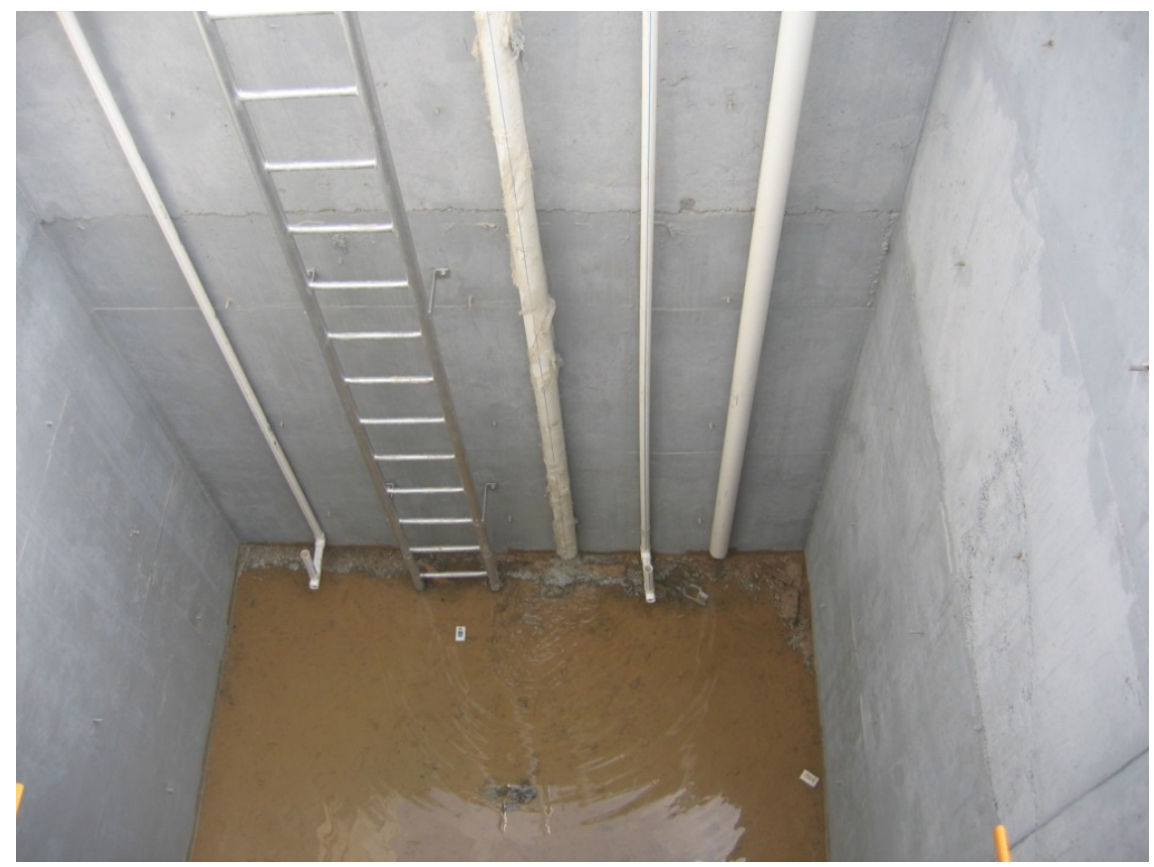

Figure 3: $\quad$ Filtrate mixing pool lines. 


\subsection{Filtrate mixing pools}

The lines within the pool include:

- The entrance line of the filtrate.

- Outside absorb line, $\mathrm{pH}$ samples.

- $\quad$ Back line, pH samples.

- Absorb line filtrate/slag to filtrate compressor.

- Chemical feeder line.

- Discharge line for ventilation blowers.

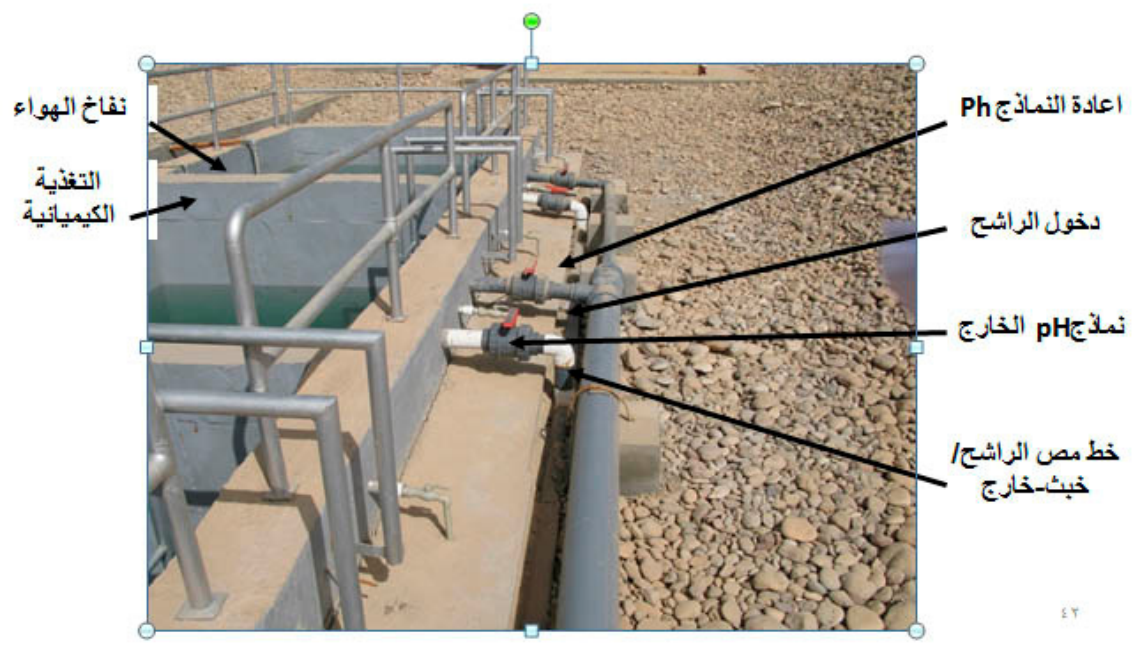

Figure 4: $\quad$ Filtrate entering line.

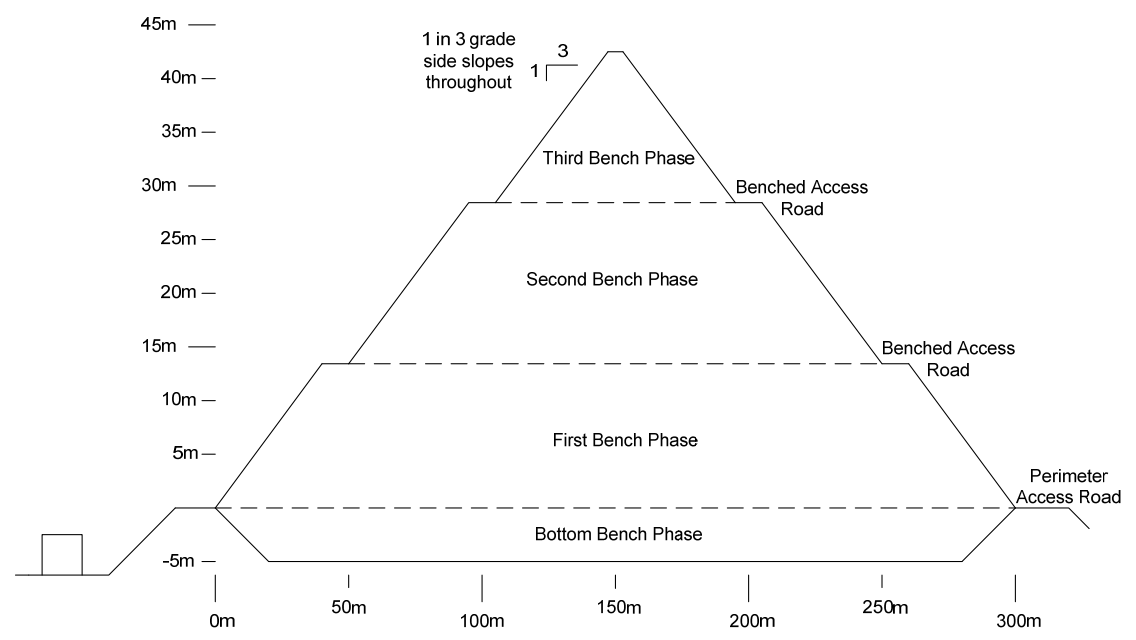




\subsection{The final coverage}

- When the burial reaches the final level; there should be final layer coverage with soil.

- The engineering cadre should do the final coverage with the cover according to the design drawings and plans.

- This coverage is necessary for the vehicles to pass, and the waste should not appear when small precipitation occurs in the levels.

- According to the developed design plans the lining layer of high density polyethylene HDPE with the gases emitted ventilation system is required [1].

\section{Extending the age of landfill}

To prolong the age:

- $\quad$ Correct and appropriate management is required.

- Laying the waste properly.

- $\quad$ The need to put plans and appropriate engineering controls in place.

- $\quad$ Techniques of landfill to manage integrated solid waste.

o Fertilization.

o Recycling.

o Campaigns to reduce the production of waste.

\section{References}

[1] Dr. Mohammad Al-Khashasha: Design and Operation of Dangerous Waste Landfills, Ministry of Environment - Jordan, Amman, 2006.

[2] Dr. Hussain Zaki: Solid Waste Management Guide, the United Nations Program for Human Settlements - Iraq 2008.

[3] Brian McCarthy: Landfill (Health Landfill) in Kirkuk, in the Area of Training, Maintenance and Management of 3 Values of the Organizational Structure and Responsibilities, the Kirkuk Provincial Reconstruction Team. 